\title{
Demonstration of cytoplasmic and nuclear antigens in acute leukaemia using flow cytometry
}

\author{
N Farahat, D van der Plas, M Praxedes, R Morilla, E Matutes, D Catovsky
}

\begin{abstract}
Aims-To detect cytoplasmic and nuclear antigens using flow cytometry in acute leukaemia and to use this technique for double marker combinations.

Methods-Cytoplasmic staining was carried out in samples from $\mathbf{4 0}$ cases of acute leukaemia with monoclonal antibodies against the myeloid antigen CD13, the lymphoid antigens CD3, CD22, $\mu$ chain and the enzymes terminal deoxynucleotidyl transferase (TdT) and myeloperoxidase (MPO). The cells were fixed with paraformaldehyde and permeabilised with Tween 20 and Becton Dickinson's FACS lysing solution. Flow cytometry results were compared in the same cases with immunocytochemistry results using the alkaline phosphatase anti-alkaline phosphatase method.

Results-The gentle permeabilisation induced by this method permitted preservation of the membrane antigens and the size and morphology of the cells. The results using flow cytometry were comparable with those obtained using immunocytochemistry, with nearly complete concordance in most cases. Conclusions-This technique is simple, rapid, sensitive and reproducible and it is suitable for double staining procedures, such as nuclear and cytoplasmic, nuclear and membrane, or cytoplasmic and membrane. It therefore provides a powerful tool for extending the use of immunophenotyping for the diagnosis and follow up of acute leukaemia. It could also be used for the investigation of minimal residual disease.
\end{abstract}

(F Clin Pathol 1994;47:843-849)

Academic

Department of

Haematology and

Cytogenetics, The

Royal Marsden

Hospital and Institute

of Cancer Research

$N$ Farahat

D van der Plas

M Praxedes

$\mathrm{R}$ Morilla

E Matutes

D Catovsky

Correspondence to:

Professor Daniel Catovsky, Academic Department of Haematology and

Cytogenetics, The Royal

Marsden Hospital, Fulham Road, London SW3 6J

Accepted for publication 28 February 1994

There has been considerable progress over the past few years in the characterisation of leukaemic cells by the use of cell markers in addition to morphological diagnosis. In acute leukaemia the findings have direct clinical and therapeutic relevance. The introduction of flow cytometry has improved the analysis of cell surface antigen expression. ${ }^{1}$ Flow cytometry allows large numbers of cells (up to $1 \times 10^{6}$ ) to be analysed over a short period of time, and the possibility of quantitating the results makes this superior to immunofluorescence microscopy and immunocytochemistry. As several of the antigens detected in blast cells are expressed first in the cytoplasm, a complete immunophenotype requires the detection not only of membrane antigens but also of intracellular ones. ${ }^{2-5}$

The most commonly used methods for detecting intracytoplasmic and nuclear antigens are immunofluorescence and immunocytochemistry on cytocentrifuge preparations of fixed cells. Although these microscopic techniques combine morphology with immunological information, they are time consuming, their results are somewhat subjective, and sometimes only a limited number of cells can be counted, giving inaccurate results. Flow cytometry for the detection of cytoplasmic and nuclear antigens has so far had limited use as the cells need to be permeabilised so that the monoclonal antibodies can reach the intracellular antigens. The reagents used for permeabilisation (fixatives and detergents) can also cause disruption of the cells with loss of antigen expression and distortion of the morphology and light scatter, so that it may not be possible to identify different cell populations. ${ }^{67}$

We describe a technique that does not disrupt the cells and preserves both antigen expression and light scatter, and permits a precise study of the leukaemic cells by gating the desired population for analysis.

\section{Methods}

Peripheral blood and bone marrow anticoagulated samples from 40 patients with acute leukaemia at presentation or relapse were studied. The diagnosis was based on morphology and cytochemistry according to the FAB criteria. $^{89}$

Mononuclear cells were isolated by density gradient centrifugation with Lymphoprep (Nycomed SA, Oslo, Norway). Cells were washed twice with Hanks's balanced salt solution before being immunostained.

\section{FIXATION AND PERMEABILISATION}

Cells $\left(0.5-1 \times 10^{6}\right)$ were used for each test. The cells were incubated for 10 minutes at room temperature with $2 \mathrm{ml}$ of a mixture of $1 \mathrm{ml} \mathrm{4 \%}$ paraformaldehyde (PFA) in phosphate buffered saline (PBS) (final concentration $2 \%$ ) and $1 \mathrm{ml}$ of a 1 in 10 dilution of Becton Dickinson's FACS lysing solution in distilled water. This is a diethylene glycol based solution that causes lysis of the red cells and mild permeabilisation of the white cells. The cells were centrifuged in an immunofuge for two minutes, the supernatant fluid discarded, and then washed with $2 \mathrm{ml}$ of $0.5 \%$ 
Table 1 Monoclonal antibodies used in this study

\begin{tabular}{|c|c|c|c|}
\hline $\begin{array}{l}\text { Monoclonal } \\
\text { antibody }\end{array}$ & $\begin{array}{l}C D \\
\text { number }\end{array}$ & $\begin{array}{l}\text { Amounts and } \\
\text { dilutions }\end{array}$ & Source \\
\hline $\begin{array}{l}\text { T3-RD1 } \\
\text { UCTH1 } \\
\text { J5-RD1 } \\
\text { MY7-RD1 } \\
\text { MCS-2 } \\
\text { B4-RD1 } \\
\text { Leu-12-PE }\end{array}$ & $\begin{array}{l}\text { CD3 } \\
\text { CD10 } \\
\text { CD13 } \\
\text { CD19 }\end{array}$ & $\begin{array}{l}5 \mu \text { l neat } \\
5 \mu \text { l neat } \\
5 \mu \text { l neat } \\
5 \mu \mathrm{l} \text { neat } \\
10 \mu \mathrm{l} \text { neat } \\
5 \mu \text { l neat } \\
20 \mu \mathrm{l} \text { neat }\end{array}$ & $\begin{array}{l}\text { Coulter Clone, Hialehah, Florida } \\
\text { University College, London } \\
\text { Coulter Clone, Hialehah, Florida } \\
\text { Coulter Clone, Hialehah, Florida } \\
\text { Nicherei Corp, Japan } \\
\text { Coulter Clone, Hialehah, Florida } \\
\text { Becton Dickinson, } \\
\text { Mountain View, California }\end{array}$ \\
\hline $\begin{array}{l}\text { MY9-RD1 } \\
\text { OKB } 22\end{array}$ & $\begin{array}{l}\text { CD33 } \\
\text { CD22 }\end{array}$ & $\begin{array}{l}5 \mu \mathrm{l} \text { neat } \\
5 \mu \mathrm{l} \text { neat }\end{array}$ & $\begin{array}{l}\text { Coulter Clone, Hialehah, Florida } \\
\text { Ortho Diagnostic System, Raritan, } \\
\text { New Jersey }\end{array}$ \\
\hline $\begin{array}{l}\text { IgM-FITC } \\
\text { Anti-MPO }\end{array}$ & & $50 \mu \mathrm{l} 1$ in 200 & Dakopatts, Glostrop, Denmark \\
\hline $\begin{array}{l}\text { MPO-1 } \\
\text { MPO-7 } \\
\text { Rabbit anti-Tdt } \\
\text { Swine anti- } \\
\text { Goat anti- } \\
\text { mouse- FITC }\end{array}$ & & $\begin{array}{l}50 \mu 11 \text { in } 10^{3} \\
5 \mu 1 \text { neat } \\
30 \mu 11 \text { in } 10 \\
30 \mu 11 \text { in } 50 \\
50 \mu 11 \text { in } 200\end{array}$ & $\begin{array}{l}\text { CBL, The Netherlands } \\
\text { Dakopatts, England } \\
\text { Seralab, Crawley Down, England } \\
\text { Seralab, Crawley Down, England } \\
\text { Cappel, North Carolina, USA }\end{array}$ \\
\hline $\begin{array}{l}\text { Goat anti- } \\
\text { mouse-PE }\end{array}$ & & $50 \mu 11$ in 20 & Dakopatts, England \\
\hline Mouse IgG-RD1 & & $5 \mu$ l neat & Coulter Clone, Hialehah, Florida \\
\hline
\end{tabular}

FITC = fluorescein isothiocyanate $\mathrm{PE}=$ phycoerythrin $\mathrm{RD}=$ rhodamine.

Tween 20 in PBS in an immunofuge for two minutes.

INDIRECT IMMUNOFLUORESCENCE STAINING

The fixed cells were incubated with the appropriate amount of each monoclonal antibody adequately titrated to find the best dilution (table 1) for 20 minutes at room temperature.

After two washes with $0.5 \%$ Tween 20 as above, the cells were incubated with fluorescein isothiocyanate (FITC)-conjugated second antibody (swine anti-rabbit or goat anti-mouse immunoglobulins) for 10 minutes at room temperature. The cells were then washed twice and resuspended in $500 \mu \mathrm{l}$ of Isoton and were then ready for analysis by flow cytometry. Negative controls were always used by treating the cells in the same way as above but omitting the first antibody.

DIRECT IMMUNOFLUORESCENCE STAINING

Antibodies directly labelled to FITC, rhodamine (RD1), or phycoerythrin (PE) were used to stain the cells in only one step followed by two washes with Tween 20 .

DOUBLE LABELLING

Membrane and cytoplasmic or nuclear

The cells were first stained for membrane antigens by incubation with $50 \mu \mathrm{l}$ of $2 \% \mathrm{AB}$ serum and the required amount of the RD1 or PE labelled monoclonal antibody for $10 \mathrm{~min}$ utes at room temperature, washed once with PBS-azide-bovine serum albumin, then fixed, permeabilised and stained for cytoplasmic or nuclear antigens with FITC labelled antibodies, as described above.

Cytoplasmic and nuclear

The cells were first fixed and permeabilised and then stained for both antibodies together. Both antibodies used for double labelling were either directly labelled, such as CD19RD1 and IgM-FITC (both were mouse antibodies), or of different species (rabbit and mouse) if one of them was not directly labelled, such as rabbit anti-TdT (not labelled) and membrane mouse anti-CD10RD1 or CD19-RD1.

Paraformaldehyde powder was obtained from Sigma (St Louis, Missouri). Polyoxyethylene(20)sorbitan monolaurate (Tween 20) was obtained from $\mathrm{BDH}$ (England). FACS lysing solution was obtained from Becton Dickinson (San José, California). Table 1 shows the antibodies used in this study.

All samples for flow cytometry were processed on a FACScan Flow cytometer (Becton Dickinson) using Lysis II software. The data were analysed after gating the leukaemic cells in the light scatter (forward scatter against side scatter) dot plot using the normal counterpart patterns as described by Carter. ${ }^{10}$

\section{IMMUNOCYTOCHEMICAL STAINING}

Cytocentrifuge slides of mononuclear cells were prepared, air dried, wrapped in foil and stored at $-20^{\circ} \mathrm{C}$ until immunocytochemical labelling. This was performed using the alkaline phosphatase-anti-alkaline phosphatase (APAAP) technique, as described elsewhere. ${ }^{11-13}$ Briefly, the slides were fixed in pure acetone for 10 minutes and air dried. Monoclonal antibodies optimally diluted were added and incubated for 30 minutes. Subsequently they were incubated for $30 \mathrm{~min}$ utes with rabbit anti-mouse immunoglobulins (Dakopatts) and for 45 minutes with mouse APAAP complexes (Dakopatts). The reaction was developed with a solution containing naphthol AS-MX phosphate (Sigma), levamisole, dimethylformamide (Merck, England) and Fast Red TR salt (Sigma) for 15 minutes. Slides were counterstained with haematoxylin-S and mounted with glycergel (Dakopatts). For TdT, an extra step was included by incubating for 30 minutes with mouse anti-rabbit immunoglobulins as second layer, followed by the rabbit anti-mouse immunoglobulins (Dakopatts).

\section{Results}

Based on morphology, FAB criteria, ${ }^{89}$ and immunophenotyping, ${ }_{13}^{13}$ the 40 cases were classified as follows: $13(32 \cdot 5 \%)$ acute lymphoblastic leukaemia (ALL), 19 (47.5\%) acute myeloid leukaemia (AML), three $(7.5 \%)$ chronic granulocytic leukaemia in blast crisis; five $(12.5 \%)$ were classified as biphenotypic.

This method is a modification of a technique supplied by Drs A Orfao and JF San Miguel from Salamanca University (personal communication) that uses Becton Dickinson lysing solution and Tween $201 \%$ for permeabilisation without prefixation of the cells. With this method the light scatter of the cells was disrupted and we were not able to identify any cell population. Our initial experiments were carried out to optimise the conditions required for the detection of intracytoplasmic and nuclear antigens for cells in suspension. Different concentrations of Tween 20 as a 

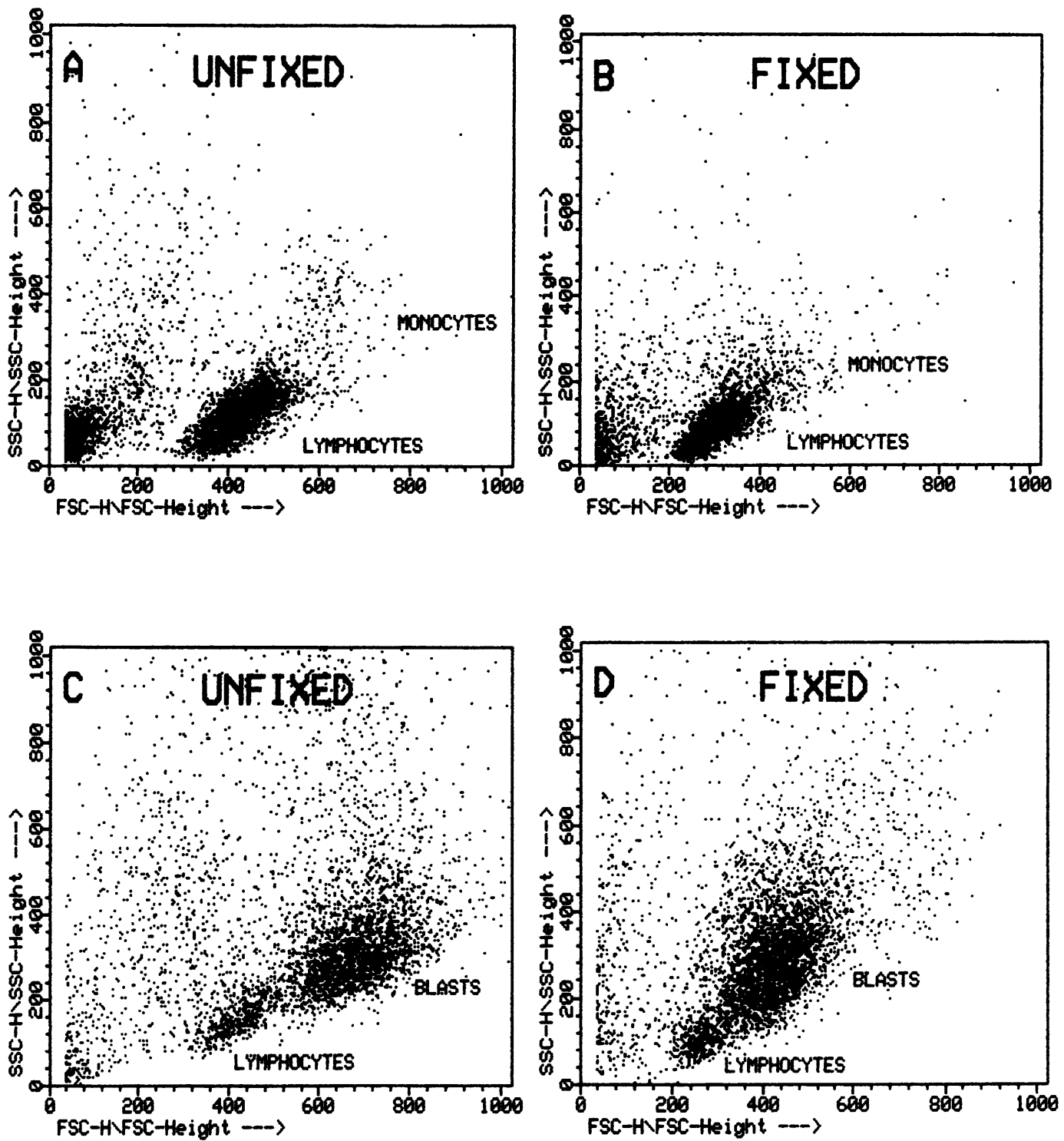

Figure 1 Effect of fixation and permeabilisation on cell scatter. $A$ and $B$ represent normal peripheral mononuclear cells and $C$ and $D$ represent a case of $A M L$. A and $C$ are untreated while $B$ and $D$ were fixed with $P F A$ and permeabilised with Becton Dickinson FACS lysing solution and Tween 20. FSC = forward scatter; SSC = side scatter.

permeabilising agent and different concentrations of PFA as fixative were used (data not shown). Tween 20 in concentrations higher than $0.5 \%$ caused disruption of the scatter and so did PFA in concentrations of less than $2 \%$. The use of Tween 20 alone in such low concentrations omitting Becton Dickinson lysing solution does not produce the required permeabilisation; therefore, we used both of them to attain full permeabilisation retaining a good scatter (fig 1). There was minimal reduction in the forward scatter (cell size) but the side scatter was unchanged, thus allowing different cell populations to be clearly recognised.

For optimal double fluorescence staining it is essential to preserve the expression of membrane antigens (figs 2 and 3). The membrane antigen expression (percentage of positive cells and fluorescence intensity) is preserved with both CD10 (stronger) and CD19 (weaker) in fig 2 and with CD19 in fig 3.

Preservation of fluorescence intensity is shown in fig 4 where there are two popula- tions of CD3 positive cells; one showing weak expression is TdT positive (blasts), the other showing strong CD3 expression is TdT negative (normal $\mathrm{T}$ lymphocytes).

In a case of biphenotypic acute leukaemia (coexpression of $\mathrm{B}$ and myeloid lineages), the blasts were positive for both TdT and MPO (fig 5).

This technique was able to demonstrate that the expression of TdT in AML and ALL is not the same. It is significantly stronger in lymphoblasts compared with myeloblasts and intermediate in ALL expressing myeloid antigens (fig 6).

To ascertain the sensitivity of this technique for detecting intracytoplasmic and nuclear antigens we compared the results with those obtained by APAAP which was the standard immunocytochemistry technique used in our laboratory. APAAP results were read independently of the results by flow cytometry. Table 2 shows the percentages of positive cells for nuclear and cytoplasmic antigens by flow cytometry (F) and APAAP (P). 
Figure $2 \quad A$ case of $A L L$ showing preservation of membrane antigen expression and fluorescence intensity. (A) represents the negative control; (B) represents double labelling of the cells for TdT and CD19; and $(C)$ represents double labelling for $T d T$ and CD10. The blasts were double positive for TdT and both CD19 and $C D 10$ and the expression of $C D 10$ is stronger than the expression of $C D 19$. $C O N=$ control; $R D 1=$ rhodamine; FITC =

fluorescein isothiocyanate.
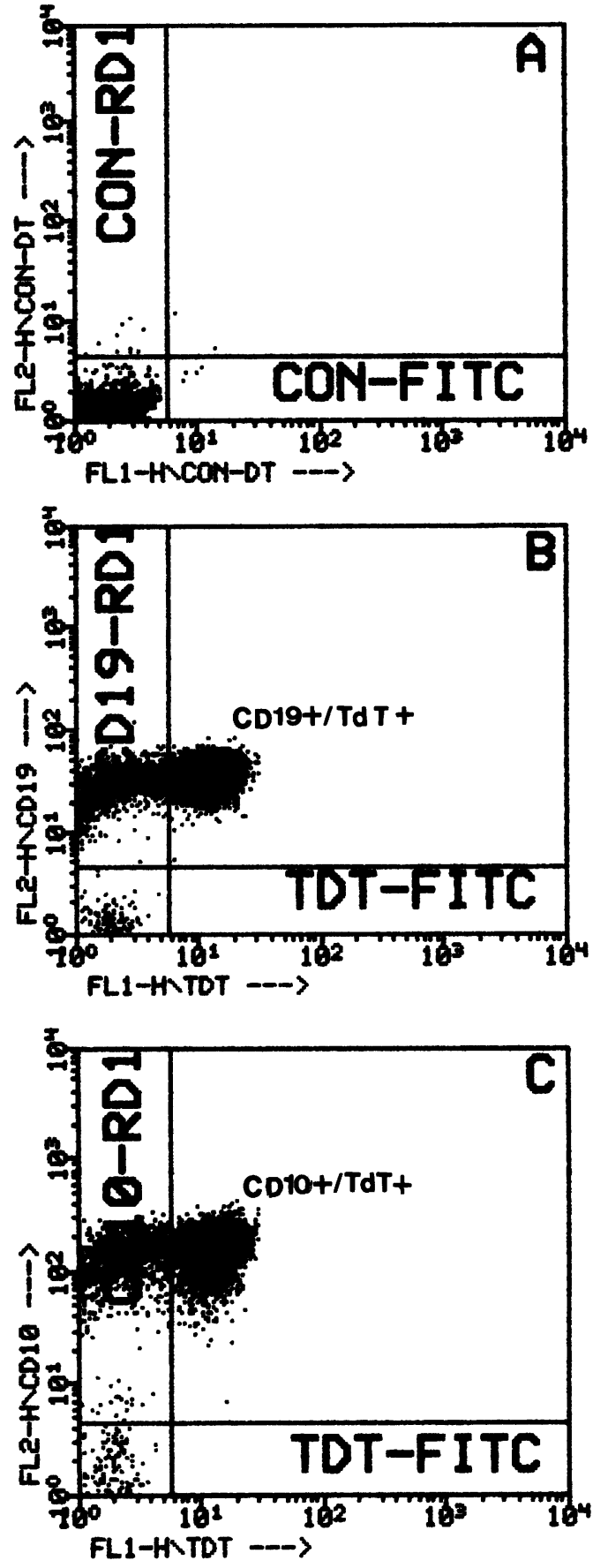

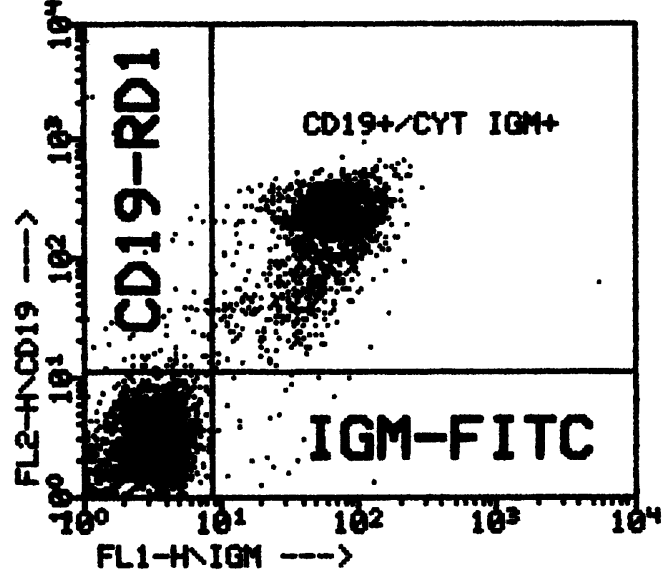

Figure $3 A$ case of Pre-B ALL. The cells were double labelled for CD19 (RD1) and cytoplasmic $\mu$ (FITC). IgM = Cytoplasmic $\mu$.

The differences (if any) in the proportion of positive cells with both methods were minimal.

Table 3 compares the number of positive cases using both techniques. Using $10 \%$ as a cutoff for TdT and MPO, and $20 \%$ for the other antibodies, we found nearly complete concordance between flow cytometry and APAAP except for CD22 where differences were observed in cases 14,34 , and 38 which were negative with one technique and positive with the other.

All the cases which were CD13 positive by flow cytometry were also positive by APAAP; however, the number of positive cells was usually lower by flow cytometry. In two cases (16 and 17) CD13 was negative on the membrane but both the blasts cells had cytoplasmic expression with equivalent results by flow cytometry and APAAP.

\section{Discussion}

We developed a fixation and permeabilisation procedure for the detection of intracytoplasmic and nuclear antigens because of their importance in the immunophenotyping of
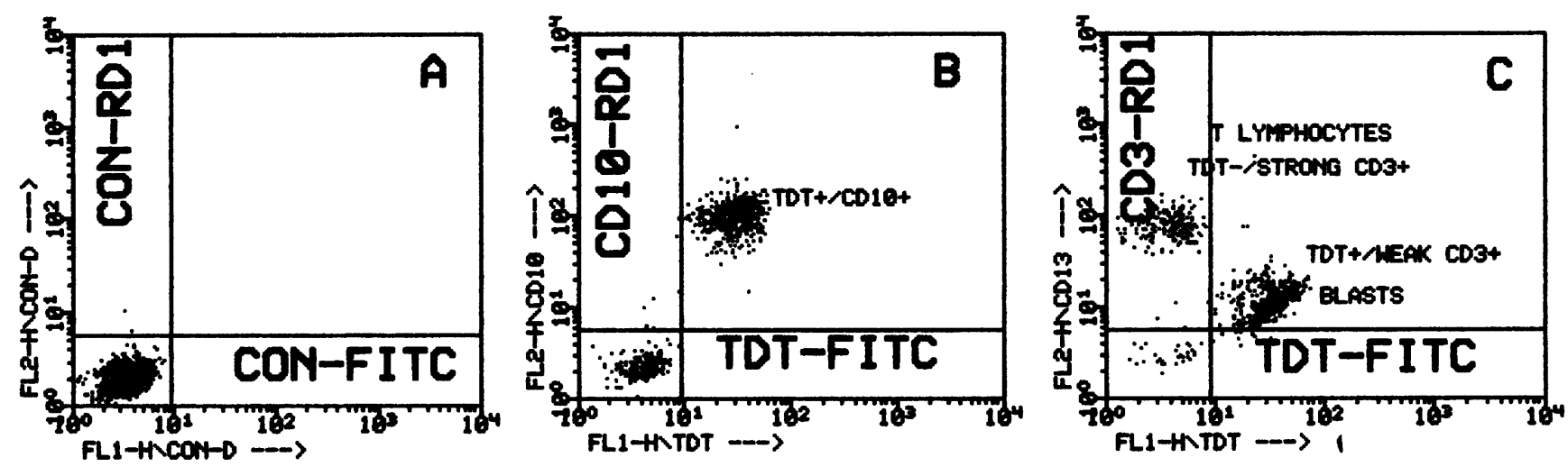

Figure $4 A$ case of biphenotypic acute leukaemia where the cells showed positivity for $T(C D 2, C D 3), B(C D 19, C D 22)$ lymphoid markers, and myeloid markers (CD13 and anti-MPO) (data not shown). (B) shows double labelling for TdT and CD10. (C) TdT and cyt CD 3 where the blasts are TdT + lcyt CD $3+$ while normal T lymphocytes are TdT-lcyt CD $3+$. 

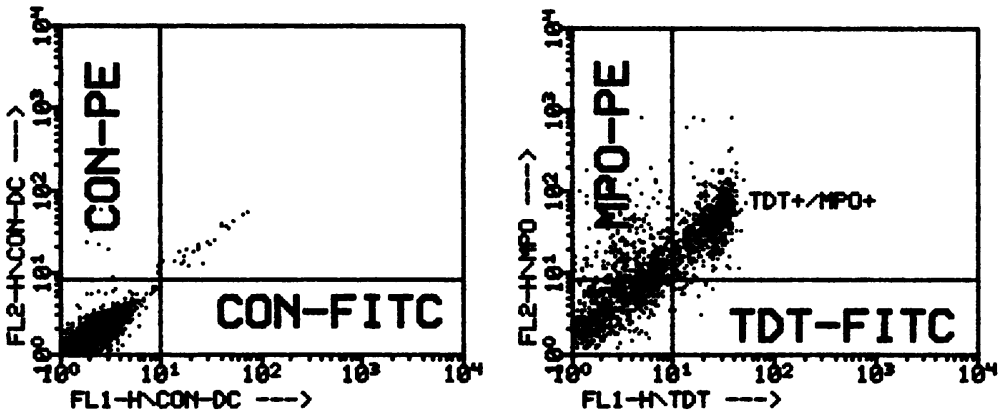

Figure 5 Double labelling for TdT (FITC) and MPO (PE) in a case of biphenotypic acute leukaemia ( $B$ lymphoid and myeloid). $M P O=$ myeloperoxidase; $P E=$ phycoerythrin.
The detection of intracytoplasmic antigens by flow cytometry has been described by several investigators using different chemicals and detergents for fixation and permeabilisation (summarised in table 4). Landy et $a l^{23}$ used formaldehyde and digitonin and noticed alteration of the scatter, but with our method there was a minimal decrease in the size of the cells (forward scatter) with no change in the side scatter, so preserving different populations.

Syrjälä et $a l^{24}$ used only Becton Dickinson FACS lysing solution for fixation and permeabilisation for the detection of TdT, but when we compared this method with ours and APAAP it gave a lower percentage of positive cells (data not shown). Slaper-Cortenbach et al ${ }^{17}$ were not able to detect TdT positivity in AML ( $n=12)$. In our study 11 of $19(57 \cdot 8 \%)$ cases of AML were TdT positive; similar findings were made by Hirata $e t a l,{ }^{18}$ who studied TdT by flow cytometry in 14 cases of AML and found that $57 \cdot 1 \%$ were positive using a cutoff of $5 \%$, and Krause $e t a l,{ }^{26}$ who detected TdT by immunoperoxidase in $44 \%$ of AML.

Using this technique we were also able to demonstrate that $\mathrm{TdT}$ expression differs in different types of acute leukaemia, being stronger in ALL, moderate in ALL with expression of myeloid antigens, and weak in AML. This confirms the observation of Adriaansen et $a l,{ }^{27}$ using fluorescence microscopy, that the intensity of TdT staining was weaker in AML than in ALL, and that of Paietta et al,,$^{20}$ who used flow cytometry, biochemical assay, and molecular analysis to prove this differential expression.

Van Der Schoot et al ${ }^{25}$ studied the expression of myeloperoxidase in AML by flow cytometry using buffered formaldehyde acetone fixation, and observed false positive results if more than $20 \%$ mature myeloid cells were present in the sample, caused by the release of MPO from these cells. Our results showed a good agreement between flow cytometry and APAAP for the demonstration of MPO. Therefore, our technique seems reliable and reproducible. Compared with other techniques, such as microscopy, it is simpler and more rapid, it does not cause cell aggregation or alteration in the morphology, nor does it affect the intensity of fluorescence, and it permeabilises both cytoplasmic and nuclear membranes.

The potential applications of this technique are many:

(1) The routine detection of cytoplasmic antigens, such as cytoplasmic $\mu$ for the diagnosis of pre-B ALL, or CD13 and MPO for the diagnosis of minimally differentiated AML (MO). Here we have confirmed our earlier observation $^{4}$ that the expression of CD13 in the cytoplasm precedes its membrane expression.

(2) Double fluorescence staining for nuclear TdT or cytoplasmic antigens and membrane antigens (the expression of which is not affected by this method) is useful for the detection and follow up of minimal residual disease in acute leukaemia after treatment. 
Table 2 Positive cells (\%) for cytoplasmic and nuclear antigens by flow cytometry (F) and APAAP (A)

\begin{tabular}{|c|c|c|c|c|c|c|c|c|c|c|c|c|c|}
\hline \multirow{2}{*}{$\begin{array}{l}\text { Case } \\
\text { No }\end{array}$} & \multirow[b]{2}{*}{ Diagnosis } & \multicolumn{2}{|l|}{$T D T$} & \multicolumn{2}{|l|}{$M P O$} & \multicolumn{2}{|l|}{$C D 22$} & \multicolumn{2}{|l|}{$C D 3$} & \multicolumn{2}{|c|}{$C D 13$} & \multicolumn{2}{|l|}{$I g M$} \\
\hline & & $F$ & $A$ & $F$ & $A$ & $F$ & $A$ & $F$ & $A$ & $F$ & $A$ & $F$ & $A$ \\
\hline $\begin{array}{l}1 \\
2 \\
3 \\
4 \\
5 \\
6 \\
7 \\
8\end{array}$ & $\begin{array}{l}\text { AML } \\
\text { MBC (CGL) } \\
\text { AML (M1) } \\
\text { AML } \\
\text { AML } \\
\text { AML } \\
\text { ALL } \\
\text { Biphenotypic } \\
\text { AL (B and M) }\end{array}$ & $\begin{array}{l}8 \\
1 \\
\text { Negative } \\
\text { Negative } \\
12 \\
30 \\
85 \\
52\end{array}$ & $\begin{array}{c}6 \\
\text { Negative } \\
\text { Negative } \\
\text { Negative } \\
11 \\
28 \\
89 \\
62\end{array}$ & $\begin{array}{l}97 \\
40 \\
81 \\
68 \\
54 \\
23 \\
\text { Negative } \\
81\end{array}$ & $\begin{array}{l}96 \\
60 \\
80 \\
84 \\
55 \\
19 \\
\text { Negative } \\
88\end{array}$ & $\begin{array}{l}\text { Negative } \\
5 \\
1 \\
5 \\
\text { Negative } \\
8 \\
46 \\
2\end{array}$ & $\begin{array}{l}\text { Negative } \\
3 \\
1 \\
6 \\
1 \\
\text { NT } \\
60 \\
1\end{array}$ & $\begin{array}{l}\text { Negative } \\
11 \\
1 \\
4 \\
7 \\
8 \\
5 \\
1\end{array}$ & $\begin{array}{l}\text { Negative } \\
9 \\
4 \\
3 \\
4 \\
\text { NT } \\
8 \\
1\end{array}$ & $\begin{array}{l}\text { NT } \\
52 \\
26 \\
62 \\
67 \\
79 \\
\text { NT } \\
\text { NT }\end{array}$ & $\begin{array}{l}\text { NT } \\
50 \\
69 \\
85 \\
90 \\
92 \\
\text { NT } \\
\text { NT }\end{array}$ & $\begin{array}{l}\text { Negative } \\
6 \\
1 \\
6 \\
9 \\
\text { NT } \\
6 \\
1\end{array}$ & $\begin{array}{l}\text { Negative } \\
2 \\
2 \\
4 \\
5 \\
\text { NT } \\
8 \\
1\end{array}$ \\
\hline $\begin{array}{r}9 \\
10\end{array}$ & $\begin{array}{l}\text { ALL } \\
\text { Biphenotypic } \\
\text { AL ( } T \text { and } M)\end{array}$ & $\begin{array}{l}72 \\
68\end{array}$ & $\begin{array}{l}87 \\
77\end{array}$ & $\begin{array}{l}\text { Negative } \\
40\end{array}$ & $\begin{array}{l}\text { Negative } \\
70\end{array}$ & $\begin{array}{l}63 \\
11\end{array}$ & $\begin{array}{r}90 \\
9\end{array}$ & $\begin{array}{r}8 \\
81\end{array}$ & $\begin{array}{r}3 \\
90\end{array}$ & $\begin{array}{l}25 \\
53\end{array}$ & $\begin{array}{l}\text { NT } \\
98\end{array}$ & $\begin{array}{l}5 \\
1\end{array}$ & $\begin{array}{l}\text { Negative } \\
1\end{array}$ \\
\hline $\begin{array}{l}11 \\
12 \\
13 \\
14 \\
15 \\
16 \\
17\end{array}$ & $\begin{array}{l}\text { AML (M5) } \\
\text { ALL } \\
\text { ALL } \\
\text { ALL } \\
\text { AML (M1) } \\
\text { ALL } \\
\text { Biphenotypic } \\
\text { AL (T, B and M) }\end{array}$ & $\begin{array}{r}4 \\
62 \\
78 \\
62 \\
39 \\
96 \\
67\end{array}$ & $\begin{array}{l}\text { Negative } \\
83 \\
80 \\
80 \\
42 \\
90 \\
75\end{array}$ & $\begin{array}{l}19 \\
\text { NT } \\
1 \\
39 \\
59 \\
3 \\
36\end{array}$ & $\begin{array}{l}22 \\
\text { NT } \\
\text { Negative } \\
20 \\
68 \\
\text { Negative } \\
50\end{array}$ & $\begin{array}{r}3 \\
61 \\
25 \\
13 \\
4 \\
59 \\
75\end{array}$ & $\begin{array}{r}2 \\
65 \\
55 \\
98 \\
2 \\
33 \\
56\end{array}$ & $\begin{array}{c}1 \\
\text { NT } \\
3 \\
4 \\
3 \\
\text { NT } \\
99\end{array}$ & $\begin{array}{l}\text { Negative } \\
\text { NT } \\
2 \\
3 \\
3 \\
\text { NT } \\
85\end{array}$ & $\begin{array}{l}60 \\
76 \\
56 \\
4 \\
25 \\
92 \\
77\end{array}$ & $\begin{array}{l}95 \\
88 \\
400 \\
\text { Negative } \\
80 \\
97 \\
37\end{array}$ & $\begin{array}{r}2 \\
5 \\
4 \\
1 \\
2 \\
20 \\
36\end{array}$ & $\begin{array}{l}\text { Negative } \\
4 \\
2 \\
4 \\
59 \\
38\end{array}$ \\
\hline $\begin{array}{l}18 \\
19 \\
20 \\
21 \\
22 \\
23 \\
24 \\
25\end{array}$ & $\begin{array}{l}\text { AML (M2) } \\
\text { CGL (BC) } \\
\text { ALL } \\
\text { AML } \\
\text { ALL } \\
\text { AML } \\
\text { AML (M4) } \\
\text { Biphenotypic } \\
\text { AL (T and M) }\end{array}$ & $\begin{array}{l}29 \\
61 \\
60 \\
\text { Negative } \\
52 \\
3 \\
\text { Negative } \\
18\end{array}$ & $\begin{array}{c}24 \\
77 \\
88 \\
1 \\
69 \\
8 \\
\text { Negative } \\
31\end{array}$ & $\begin{array}{l}70 \\
15 \\
7 \\
76 \\
\text { Negative } \\
\text { NT } \\
57 \\
23\end{array}$ & $\begin{array}{l}74 \\
12 \\
\text { Negative } \\
90 \\
\text { Negative } \\
\text { NT } \\
80 \\
10\end{array}$ & $\begin{array}{l}1 \\
\text { Negative } \\
74 \\
7 \\
31 \\
5 \\
13 \\
\text { Negative }\end{array}$ & $\begin{array}{c}3 \\
10 \\
80 \\
1 \\
73 \\
7 \\
5 \\
\text { Negative }\end{array}$ & $\begin{array}{r}5 \\
5 \\
2 \\
8 \\
6 \\
15 \\
2 \\
\text { NT }\end{array}$ & $\begin{array}{r}11 \\
11 \\
4 \\
19 \\
4 \\
12 \\
5 \\
N T\end{array}$ & $\begin{array}{l}35 \\
\text { NT } \\
1 \\
54 \\
\text { NT } \\
\text { NT } \\
48 \\
\text { NT }\end{array}$ & $\begin{array}{l}67 \\
\text { NT } \\
\text { Negative } \\
65 \\
\text { NT } \\
\text { NT } \\
50 \\
\text { NT }\end{array}$ & $\begin{array}{l}6 \\
\text { Negative } \\
1 \\
4 \\
31 \\
5 \\
\text { NT } \\
\text { NT }\end{array}$ & $\begin{array}{r}5 \\
1 \\
5 \\
5 \\
65 \\
9 \\
\text { NT } \\
\text { NT }\end{array}$ \\
\hline $\begin{array}{l}26 \\
27 \\
28 \\
29 \\
30 \\
31\end{array}$ & $\begin{array}{l}\text { AML } \\
\text { AML } \\
\text { ALL } \\
\text { ALL } \\
\text { ALL } \\
\text { Biphenotypic } \\
\text { AL (B and } M \text { ) }\end{array}$ & $\begin{array}{l}51 \\
40 \\
75 \\
92 \\
98 \\
58\end{array}$ & $\begin{array}{r}57 \\
41 \\
95 \\
95 \\
100 \\
65\end{array}$ & $\begin{array}{r}40 \\
95 \\
3 \\
1 \\
\text { NT } \\
\text { NT }\end{array}$ & $\begin{array}{l}47 \\
98 \\
2 \\
\text { Negative } \\
\text { NT } \\
\text { NT }\end{array}$ & $\begin{array}{l}\text { NT } \\
\text { NT } \\
\text { NT } \\
\text { NT } \\
\text { NT } \\
\text { NT }\end{array}$ & $\begin{array}{l}\text { NT } \\
\text { NT } \\
\text { NT } \\
\text { NT } \\
\text { NT }\end{array}$ & $\begin{array}{l}\text { NT } \\
\text { NT } \\
\text { NT } \\
\text { NT } \\
\text { NT }\end{array}$ & $\begin{array}{l}\text { NT } \\
\text { NT } \\
\text { NT } \\
\text { NT } \\
\text { NT } \\
\text { NT }\end{array}$ & $\begin{array}{l}\text { NT } \\
\text { NT } \\
\text { NT } \\
\text { NT } \\
\text { NT } \\
\text { NT }\end{array}$ & $\begin{array}{l}\text { NT } \\
\text { NT } \\
\text { NT } \\
\text { NT } \\
\text { NT } \\
\text { NT }\end{array}$ & $\begin{array}{l}\text { NT } \\
\text { NT } \\
\text { NT } \\
\text { NT } \\
\text { NT } \\
\text { NT }\end{array}$ & $\begin{array}{l}\text { NT } \\
\text { NT } \\
\text { NT } \\
\text { NT } \\
\text { NT } \\
\text { NT }\end{array}$ \\
\hline $\begin{array}{l}32 \\
33 \\
34 \\
35 \\
36 \\
37 \\
38 \\
39 \\
40\end{array}$ & $\begin{array}{l}\text { AML } \\
\text { AML } \\
\text { ALL } \\
\text { AML (M5b) } \\
\text { AML (M2) } \\
\text { CGL (BC) } \\
\text { AML } \\
\text { AML } \\
\text { ALL }\end{array}$ & $\begin{array}{l}23 \\
1 \cdot 4 \\
23 \\
62 \\
22 \\
93 \\
22 \\
33 \\
81\end{array}$ & $\begin{array}{l}31 \\
\text { Negative } \\
\text { NT } \\
49 \\
19 \\
93 \\
25 \\
41 \\
98\end{array}$ & $\begin{array}{l}\text { NT } \\
86 \\
10 \\
98 \\
90 \\
62 \\
4 \\
88 \\
3\end{array}$ & $\begin{array}{l}\text { NT } \\
90 \\
\text { NT } \\
\text { NT } \\
90 \\
84 \\
5 \\
78 \\
6\end{array}$ & $\begin{array}{l}\text { NT } \\
6 \\
29 \\
\text { Negative } \\
\text { NT } \\
76 \\
10 \\
7 \\
50\end{array}$ & $\begin{array}{l}\text { NT } \\
2 \\
7 \\
\text { Negative } \\
\text { NT } \\
90 \\
25 \\
14 \\
64\end{array}$ & $\begin{array}{c}\text { NT } \\
3 \\
13 \\
1 \\
2 \\
7 \\
\text { NT } \\
\text { NT } \\
2\end{array}$ & $\begin{array}{l}\text { NT } \\
2 \\
10 \\
5 \\
4 \\
2 \\
\text { NT } \\
\text { NT } \\
12\end{array}$ & $\begin{array}{l}\text { NT } \\
91 \\
43 \\
93 \\
91 \\
91 \\
56 \\
44 \\
1\end{array}$ & $\begin{array}{l}\text { NT } \\
68 \\
21 \\
73 \\
90 \\
87 \\
65 \\
64 \\
\text { Negative }\end{array}$ & $\begin{array}{c}\text { NT } \\
3 \\
7 \\
7 \\
\text { Negative } \\
4 \\
9 \\
\text { NT } \\
1\end{array}$ & $\begin{array}{l}\text { NT } \\
5 \\
6 \\
2 \\
\text { Negative } \\
15 \\
3 \\
\text { NT } \\
1\end{array}$ \\
\hline
\end{tabular}

IGM = cytoplasmic $\mu$; CGL $(\mathrm{BC})=$ Blastic crisis of chronic granulocytic leukaemia; NT = not tested.

Table 3 Comparison of number of positive cases tested by flow cytometry $(F)$ and APAAP (A)

\begin{tabular}{|c|c|c|c|c|c|c|c|c|c|c|c|}
\hline \multicolumn{2}{|c|}{$\begin{array}{l}T D T+ \\
(n=40)\end{array}$} & \multicolumn{2}{|c|}{$\begin{array}{l}M P O+ \\
(n=34)\end{array}$} & \multicolumn{2}{|c|}{$\begin{array}{l}C D 22^{*} \\
(n=29)\end{array}$} & \multicolumn{2}{|c|}{$\begin{array}{l}C D 3 \\
(n=26)\end{array}$} & \multicolumn{2}{|c|}{$\begin{array}{l}C D 13 \\
(n=25)\end{array}$} & \multicolumn{2}{|c|}{$\begin{array}{l}\text { Cytoplasmic IgM } \\
(n=27)\end{array}$} \\
\hline$F$ & $A$ & $F$ & $A$ & $F$ & $A$ & $F$ & $A$ & $F$ & $A$ & $F$ & $A$ \\
\hline 31 & 31 & 24 & 24 & 11 & 12 & 2 & 2 & 22 & 22 & 3 & 3 \\
\hline
\end{tabular}

*Cases $14,34,38$ were positive by one technique and negative by the other.

tCutoff of positivity was $10 \%$ while in the others it was $20 \%$.

Table 4 Published reports on cytoplasmic and nuclear antigen detection using flow cytometry

\begin{tabular}{|c|c|c|c|}
\hline \multirow[b]{2}{*}{ Reference } & \multicolumn{2}{|l|}{ Technique } & \multirow[b]{2}{*}{ Comments } \\
\hline & Fixation & Permeabilisation & \\
\hline 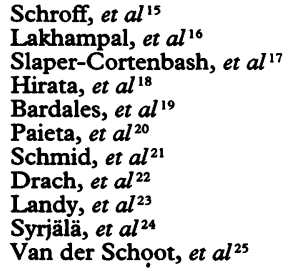 & $\begin{array}{l}\text { PFA and ethanol } \\
\text { PFA and ethanol } \\
\text { BFA } \\
\text { Formalin } \\
\text { PFA } \\
\text { PFA } \\
\text { PFA } \\
\text { BFA } \\
\text { Formalin } \\
\text { BFA }\end{array}$ & $\begin{array}{l}\text { Lysolecithin } \\
\text { Tween } 20 \text { and methanol } \\
\text { Saponin } \\
\text { Tween } 20 \\
\text { Saponin } \\
\text { Digitonin } \\
\text { BD FACS lysing solution }\end{array}$ & $\begin{array}{l}\text { Detects anti-intermediate filament antigen } \\
\text { Double staining for membrane antigens and DNA } \\
\text { Detects CD3, CD22, TdT and Cyt. } \mu \\
\text { Detects TdT } \\
\text { Detects TdT } \\
\text { Detects TdT } \\
\text { Double staining for surface antigens and DNA, detection of cyt CD3 and } \mu \\
\text { Detects MPO, CD3, CD22 } \\
\text { Double staining for membrane and cytoplasmic antigens } \\
\text { Detection of TdT } \\
\text { Detects MPO }\end{array}$ \\
\hline
\end{tabular}


(3) For the rapid diagnosis of biphenotypic acute leukaemia by being able to use the full range of reagents to diagnose such cases which may require more intensive treatment protocols.

We conclude that the technique described provides a powerful tool for improving the application of immunophenotyping to the diagnosis, follow up, and overall management of all types of acute leukaemia. We expect that nuclear and cytoplasmic staining by flow cytometry may replace in the near future the need for performing immunocytochemistry on fixed cells in many of its current applications in the immunophenotyping of leukaemic blast cells.

This work was supported by a grant of the Egyptian government (NF), the Cancer Research Campaign (RM, EM), and the Dutch government (DvP). We are grateful to Drs A Orfao and JF San Miguel from Salamanca University for their advice.

1 Shapiro HM. Practical flow cytometry. New York: Alan R Liss Inc, 1985.

2 Campana D, Thompson JS, Brown S, Janossy G. The cytoplasmic expression of $\mathrm{CD} 3$ antigens in normal and malignant cells of the $\mathrm{T}$ lymphoid lineage. $\mathcal{F}$ Immunol 1987;138:648-55.

3 Mason DY, Stein H, Gerdes J, Pulford KAF, Ralfkiaer E, Falini B, et al. Value of monoclonal anti-CD22 (p135) antibodies for the detection of normal and neoplastic B antibodies for the detection of normal
lymphoid cells. Blood 1978;69:836-40.

4 Pombo de Oliveira MS, Matutes E, Rani S, Morilla R Catovsky D. Early expression of MCS-2 (CD13) in the cytoplasm of blast cells from acute myeloid leukaemia. Acta Haematol 1988;80:61-4.

5 Van Dongen JM, Krissansen GW, Wolvers-Tettero ILM, Comans-Bitter WM, Adriaansen HJ, Hooijkaas $\mathrm{H}$, et al. Cytoplasmic expression of the $\mathrm{CD} 3$ antigen as a diagnostic marker for immature $\mathrm{T}$ cell malignancies. Blood 1988;71:603-12.

6 Halldén G, Andersson U, Hed J, Johansson SGO. A new membrane permeabilization method for the detection of intracellular antigens by flow cytometry. $\mathcal{f}$ Immunol Methods 1989;124:103-9.

7 Andersson U, Halldén G, Persson U, Hed J, Moller G, Deley $M$. Enumeration of IFN- $\tau$-producing cells by flow cytometry: comparison with fluorescence microscopy f Immunol Methods 1988;112:139-42.

8 Bennett JM, Catovsky D, Daniel MT, Flandrin G, Galton DAG, Gralnick HR, et al. Proposed revised criteria for the classification of acute myeloid leukaemia. Ann Intern Med 1985;103:620-5.

9 Bennett JM, Catovsky D, Daniel MT, Flandrin G, Galton DAG, Gralnick HR, et al. Proposals for the classification of the acute leukaemias: French-American-British (FAB) cooperative. Br f Haematol 1976;33:451-8.

10 Carter NP. Measurement of cellular subsets using antibodies. In: Ormerod MG, ed. Flow cytometry. A practical approach. First edition. New York: Oxford University approach. First edition
11 Cordell JL, Falini B, Erber WN, Mason DY. Immunoenzymatic labelling of monoclonal antibodies using immune complexes of alkaline phosphatase and monoclonal anti-alkaline phosphatase (APAAP complexes). F Histochem Cytochem 1984;32:219-29.

12 Erber WN, Mason DY. Immunoalkaline phosphatase labelling of terminal transferase in hematological samples. Am $\mathcal{F}$ Clin Pathol 1986;88:43-50.

13 Buccheri V, Shetty V, Yoshida N, Morilla R, Matutes E Catovsky $D$. The role of anti-myeloperoxidase antibody in the diagnosis and classification of acute leukaemia. A comparison with light and electron microscopy cytochemistry. Br f Haematol 1991;80:62-5.

14 Williams CA, Chase MW, eds. Methods in immunology and immunocytochemistry. Vol V. New York: Academic Press, 1976.

15 Schroff RW, Bucana CD, Klein RA, Farrell MM, Morgan AC Jr. Detection of intracytoplasmic antigens by flow AC Jr. Detection of intracytoplasmic antigens

16 Lakhanpal S, Gonchoroff NJ, Katzmann JA, Handwerger BS. A flow cytofluorometric double staining technique for simultaneous determination of human mononuclear cell surface phenotype and cell cycle phase. $\mathcal{F}$ Immuno Methods 1987;96:35-40.

17 Slaper-Cortenbach ICM, Admiraal LG, Kerr JM, van Leeuwen EF, von dem Borne AEGK, Tetteroo PAT Flow cytometric detection of terminal deoxynucleotidyl transferase and other intracellular antigens in combination with membrane antigens in acute lymphatic leukemias. Blood 1988;72:1639-44.

18 Hirata $M$, Okamoto $Y$. Enumeration of terminal deoxynucleotidyl transferase positive cells in leukemia/lymphoma cleotidyl transferase positive cells in leukemia/

19 Bardales RH, Carrato A, Fleischer M, Schwartz MK Koziner B. Detection of terminal deoxynucleotidy transferase (TdT) by flow cytometry in leukemic disorders. $\mathcal{F}$ Histochem Cytochem 1989;37:509-13.

20 Paietta E, Racevskis J, Bennett JM, Wiernik PH Differential expression of terminal transferase (TdT) in acute lymphocytic leukaemia expressing myeloid antigens and TdT positive acute myeloid leukaemia as compared to myeloid antigen negative acute lymphocytic leukaemia. Br f Haematol 1993;84:416-22.

21 Schmid I, Uittenbogaart $\mathrm{CH}$, Giorgi JV. A gentle fixation and permeabilization method for combined cell surface and intracellular staining with improved precision in and intracellular staining with improved precisic

22 Drach D, Drach J, Glassl H, Gattringer C, Huber H. Flow cytometric detection of cytoplasmic antigens in acute leukemias: implications for lineage assignment. Leuk Res 1993;17:455-61.

23 Landay A, Jennings C, Forman M, Raynor R. Whole blood method for simultaneous detection of surface and cytoplasmic antigens by flow cytometry. Cytometry 1993;14:433-40.

24 Syrjälä MT, Tiirikainen M, Jansson SE, Krusius T. Flow cytometric analysis of terminal deoxynucleotidyl transferase. A simplified method. Am 7 Clin Pathol 1993; 99:298-303.

25 van der Schoot CE, Daams GM, Pinkster J, Vet $R$, von dem Borne AEGK. Monoclonal antibodies against myeloperoxidase are valuable immunological reagents for the diagnosis of acute myeloid leukaemia. $\mathrm{Br} f$ for the diagnosis of acute
Haematol 1990;74:173-8.

26 Krause JR, Brody JP, Kaplan SS, Penchansky L. Termina deoxynucleotidyl transferase activity in acute leukemia: A study of 100 cases comparing an immunoperoxidas (PAP) vs immunofluorescent method. $\mathrm{Am} \mathcal{7}$ Hemato 1986;22:179-84.

27 Adriaansen HJ, Hooijkaas H, Kappers-klunne MC, van't Veer MB, van Dongen JIM. Double marker analysis for terminal deoxynucleotidyl transferase and myeloid antigens in acute nonlymphocytic leukaemia patients and healthy subjects. Haematology and Blood Transfusion 1990;33:41-9. 